\title{
Chemical constituents of Sandbox Tree (Hura crepitans Linn.) and Anti-hepatotoxic Activity of the Leaves and Stem Bark Extracts \\ GK Oloyede ${ }^{1}$, OA Adaramoye ${ }^{2}$, MB Olatinwo ${ }^{1}$
}

\begin{abstract}
Objectives: The use of natural products derived from plants for therapeutic purpose is as ancient as human civilization. Sandbox tree, Hura crepitans L. (Euphorbiaceae) is one of such plant and has been reported to have many ethnomedicinal applications especially as antimicrobial, antiinflammatory and antihepatotoxic effects. This recent study was designed to determine the antihepatotoxic activity of the ethylacetate soluble fraction of the leaves and stem bark of $H$. crepitans and to isolate secondary metabolites.
\end{abstract}

Methods: Chromatographic technique was used for isolation and Ultraviolet-Visible (UV), Infra-red (IR) and Nuclear Magnetic Resonance (NMR) spectroscopies were used for structural elucidation. Anti-hepatotoxicity study was carried out using carbon tetrachloride $\left(\mathrm{CCl}_{4}\right)$ induced rat model and biochemical parameters: alanine aminotransferase (ALT), aspartate aminotransferase (AST), L- $\gamma$ glutamyltransferase (GGT), urea and creatinine (CREA) were assayed on the serum. Phytomicrographs of the liver samples were also taken and analyzed.

Results: Our present study showed that biochemical studies of blood samples of $\mathrm{CCl}_{4}$ treated rats with value 105.0 $\pm 0.001 \mathrm{AU}$ in ALT showed significant increase in the level of serum enzyme activities reflecting liver injury but, 69.0 $\pm 13.23 \mathrm{AU}$ for leaves and 53.3 $\pm 2.52 \mathrm{AU}$ for bark $(\mathrm{p}<0.05)$ indicated protection of hepatic cells. AST, GGT, urea and CREA also reduced significantly. Daphnane diterpenes, daphnetoxin acid and huratoxin were isolated from $H$. crepitans in this recent study along with apocynin and methylpentadecanoate.

Conclusion: H. crepitans significantly reduced the level of biochemical parameters indicating protection against hepatocellular injury. Isolates obtained from this plant could also serve as lead compounds in therapy of diseases involving hepatic injury.

Keywords: Apocynin, daphnane diterpenes, hepatoprotective, histopathology, methylpentadecanoate From: ${ }^{1}$ Natural products/Medicinal Chemistry Unit, Department of Chemistry, University of Ibadan, Nigeria. ${ }^{2}$ Department of Biochemistry, University of Ibadan, Nigeria.

Correspondence: Dr GK Oloyede, Natural products/Medicinal Chemistry Unit, Department of Chemistry, University of Ibadan, Nigeria. E-mail: gk.oloyede@ui.edu.ng/oloyedegk@gmail.com 


\section{INTRODUCTION}

Mineral, plant and animal products were the main sources of drugs for a long time and the use of these natural products with therapeutic properties is as ancient as human civilization (1-2). But recently, interest in therapeutic use of natural products, especially those derived from plants deepened because report has it that certain percentage of drugs prescribed worldwide and those considered as basic and essential by the World Health Organization (WHO) are exclusively of plant origin or many are synthetic drugs obtained from lead compounds (1-3). Examples of important drugs obtained from medicinal plants are morphine and codeine from Papaver somniferum, artemisinin from Artemesia annua, vincristrine and vinblastine from Catharanthus roseus, digoxin from Digitalis spp., quinine and quinidine from Cinchona spp., and atropine from Atropa belladona. The importance of these natural products cannot be overemphasized as these secondary plant metabolites can be lead compounds, allowing for the design and rational planning of new drugs, development and the discovery of new therapeutic properties not yet attributed to known compounds. In addition, compounds such as physostigmine, cannabinoids and yohimbine obtained from plants, are important tools used in pharmacological, physiological and biochemical studies (1-8).

Sandbox tree, Hura crepitans L. (Euphorbiaceae), a plant common to the tropics has been reported to have many ethnomedicinal applications especially as antimicrobial, antiinflammatory and antihepatotoxic effects (9). Adedire and Ajayi (2003) (10) reported the insecticidal activity of the seed oil. Huratoxin was isolated from the milky sap of $H$. crepitans along with hexahydrohuratoxin and keto-enal. Crepitin is also a toxalbumin derived from $H$. crepitans and has been shown to be toxic (11-12). Hurain, the proteolytic enzyme of the sap of $H$. crepitans, has also been reported to be activated by $\mathrm{Fe}^{2+}$ and inhibited by $\mathrm{Ni}^{2+}, \mathrm{Zn}^{2+}$, $\mathrm{Cd}^{2+}$ and $\mathrm{Cl}^{-}$ions; its activity diminished in the presence of trypsin inhibitors from soy bean, black bean and Ascaris lumbricoides (13-14). Lectins which are carbohydrate-binding 
proteins, specific for sugar moieties were isolated from the latex of $H$. crepitans L. and Euphorbia characias L. (Mediterranean spurge) (15). Recently, phytochemicals such as glycosides, alkaloids, flavonoids, tannins was reported in the seed oil (16-18). The presence of some fatty acids, sterols and acyclic aliphatic ketones in the root of $H$. crepitans has also been reported (19) while antimicrobial activity of the extracts from leaves and stem bark; chemical composition and antimicrobial activity of essential oil of $H$. crepitans leaf (20) have also been investigated. Not much report of the nature of secondary metabolites and pharmacological activity of the aerial parts of $H$. crepitans L. (leaf, stem or stem bark) was found in literature. The objective of this research work therefore was to isolate, purify and characterize the chemical constituents in H. crepitans leaves and stem bark and to screen the ethylacetate soluble fraction for hepatoprotective activity against carbontetrachloride-induced liver damage in rats since it has been established in a separate assay that $H$. crepitans ethylacetate fraction has antioxidant activity when compared to other fractions (21). Plants with antioxidant activity have been observed to have protective effect against hepatic injury (22). Hepatotoxicity implies chemical-driven liver damage. Liver plays a central role in transforming and clearing chemicals and is susceptible to the toxicity from these agents. There are different kinds of disease conditions that affect the liver, some of which are liver cirrhosis, hepatitis, liver cancer amongst others. Chemicals that cause liver injury or damage are called hepatotoxins and more than 900 drugs have been implicated in causing liver damage. Hepatotoxic substances that are commonly used for in vivo and in vitro assays are $\mathrm{CCl}_{4}$, vinyl chloride, bromobenzene and ethanol (23-24). 


\section{MATERIALS AND METHODS}

\section{Plant collection and identification}

Fresh leaves and stem bark of $H$. crepitans were identified and authenticated by $\mathrm{Mr}$ E. Donatus of the Herbarium unit of Department of Botany and Microbiology of the Faculty of Science University of Ibadan and were collected in September 2009 at the Botanical Gardens, University of Ibadan, Ibadan, Oyo state, Nigeria. This plant was also compared and found to be the same with a Herbarium specimen labelled FRIN 10565 at Forestry Research Institute of Nigeria, Ibadan, Oyo state, Nigeria.

\section{Animals}

Adult Wistar (albino) rats of average weight $160 \mathrm{~g}$ (14 weeks old) bred in the animal house of the Department of Biochemistry, University of Ibadan were used. The animals were divided into 8 groups. Five animals were used per group. The rats were kept at $27 \pm 2^{0} \mathrm{C}$ for 1 week before and during the experiments and were fed with balanced livestock feeds from Pfizer, Plc and water, ad libitum. The animal experimental protocol was approved by the Institutional Animal Ethics Committee.

\section{Chemicals and Reagents}

Hexane, ethyl acetate (EtOAc), methanol (MeOH), butanol (BuOH), chloroform, hydrochloric acid, naphthol, bismuth nitrate, potassium iodide, sodium hydroxide, copper acetate, $\mathrm{NaOH}$, sodium chloride, copper sulphate pentahydrate, ferric chloride, conc. tetraoxosulphate (VI) acid, conc. $\mathrm{HCl}$, ammonia solution, sodium potassium tartarate, potassium chloride, glacial acetic acid, Molisch reagent, Dragendroff's reagent, disodium hydrogen phosphate, dihydrogen potassium phosphate, iodine crystals, copper acetate, carbon tetrachloride were all BDH (England) chemicals and solvents (distilled prior to use), silica gel 70-230 microns (Merck, Germany), and Randox Laboratory kits for biochemical assays (Randox, UK). 


\section{Equipment and Apparatus}

Soxhlet apparatus and condenser (Pyrex, UK), Mettler analytical balance H80 (Mettler, UK), Water Bath (Gallenkamp, UK), Rotavapor RII0 (Buchi, England), silica gel GF $_{254}$ (precoated aluminium sheets - Merck Germany), Centrifuge (Gallenkamp, UK), pH meter (Jenway model, UK), Astel Hearson Oven (Gallenkamp, UK), Teflon Homogenizer (Gallenkamp, UK), UV-Visible spectrophotometer (UVD-2960 model equipped with a UVWIN software version LABOMED INC, USA), IR Spectrophotometer (Perkin Elmer FTIR system, Spectrum BX model of IR Spectrophotometer, England), Varian-Mercury NMR Spectrophotometer (England) operating at $200 \mathrm{MHz}$ for $\mathrm{H}$ and $50 \mathrm{MHz}$ for $\mathrm{C}$ nuclei.

\section{Sample preparation, extraction and fractionation procedure}

The leaves and stem bark of $H$. crepitans were weighed separately and air-dried for 4 and 6 weeks respectively until the weight was constant and then pulverized using mill machine at the Wood extraction laboratory, Department of Chemistry, University of Ibadan. The pulverized dried leaves $(3.5 \mathrm{~kg})$ and bark $(2.5 \mathrm{~kg})$ were extracted with $6.0 \mathrm{~L}$ and $5.0 \mathrm{~L}$ of distilled methanol respectively. Methanol was used to mimic local gin (alcohol) used in preparation of the plant $H$. crepitans in folklore medicine. Soxhlet apparatus was used for extraction since it has the tendency of extracting large amount of plants giving high yield within the shortest possible time. The extracts were collected and concentrated with the aid of Bucchi rotavapor at $37{ }^{0} \mathrm{C}$ and partitioned into various fractions with distilled water, hexane, ethylacetate and butanol in other to separate plant constituents based on polarity. The EtOAc and $\mathrm{BuOH}$ fractions of leaves and EtOAc fraction of bark obtained above were subjected to column chromatography using silica gel of mesh size 70-230 microns (activated in an oven at $105^{\circ} \mathrm{C}$ for $1 \mathrm{hr}$ ) as adsorbent. Slurry of adsorbent was prepared by mixing activated silica gel with n-hexane in optimum proportion (ratio of silica gel to extract was 30:1) and wet-packed into the column gently to avoid air-bubbles and cracking which could affect the resolution. 
Ethylacetate and butanol fractions (15 g each) of the leaves and bark were pre-adsorbed in silica gel and dried before loading onto the column. Hexane was used to wash the packed column prior to analysis. The loaded sample was then covered with pure white sand and small piece of cotton wool. The top of the column was usually filled with enough solvent/mixture of solvents to avoid cracking. The elution started with $100 \%$ non-polar hexane after which the polarity of the solvent(s) was increased gradually with EtOAc and methanol in a gradient elution chromatographic technique. $25 \mathrm{ml}$ of each of the eluents was collected. The purity of the fractions was assessed by thin layer chromatographic analysis (TLC) using pre-coated aluminium TLC plates. The spotted plate was developed in different solvent systems depending on the degree of polarity of each constituent at room temperature. If not coloured after development, it was visualized in the iodine tank. Solvent systems used were Hexane/EtOAc (1:1), (3:1), (1:3), (4:1); Hexane/MeOH (1:1), (1:3), (3:1), (1:4); Hexane/Ethanol (1:1), (1:2), (2:1), (1:3), (4:1), (1:4) and Hexane/EtOAc/MeOH (1:1:1), $(3: 1: 1),(4: 1: 1),(2: 1: 4)$.

\section{Elution of fractions}

A total of 126 ethylacetate fractions of leaves were collected, analyzed using TLC and pooled according to $\mathrm{R}_{\mathrm{f}}$ values; $1-5(\mathrm{H} 1), 6-11(\mathrm{H} 2), 12-19(\mathrm{H} 3), 20-22(\mathrm{H} 4), 23-33$ (H5), 34-45 (H6), 46-52 (H7), 53-58 (H8), 59-74 (H9), 75-81 (H10), 82-91 (H11), 92-95 (H12), 96-101 (H13), 102-103 (H14), 104-126 (H15). Fraction 53-58 obtained as solid crystals was recrystallized to obtain a dark greenish substance tagged Ola 3. Butanol fraction of leaves gave 117 fractions, analyzed using TLC and pooled accordingly; 1-6 (C1), 7-16 (C2), 17-30 (C3), 31-40 (C4), 41-53 (C5), 54-69 (C6), 70-85 (C7), 86-101 (C8), 102-117 (C9). Fraction 17-30 obtained as solid crystals was recrystallized to give a dark brownish solid (Ola 5). While elution of ethylacetate fraction of $H$. crepitans stem bark gave 153 fractions and analyzed using TLC. Fractions having the same $\mathrm{R}_{\mathrm{f}}$ value were bulked accordingly: 1-11 (HC1), 12-16 (HC2), 25- 
31 (HC3), 32-40 (HC4), 41-53 (HC5), 54-69 (HC6), 70-85 (HC7), 86 (HC8), 87 (HC9), 88100 (HC10), 101-119 (HC11), 120-153 (HC12). Fractions 25-31 and 87 which gave single spots when analyzed by TLC were purified to obtain dark greenish solids named Ola 2 and Ola 1 respectively while fraction 88-100 (brown solid; Ola 4) was obtained in small yield. Analysis of the isolates: Spectroscopic techniques; UV, IR and NMR were used for structural elucidation. Samples $(0.01 \% \mathrm{w} / \mathrm{v})$ were scanned between $190 \mathrm{~nm}$ and $400 \mathrm{~nm}$ with the aid of UVD-2960 model UV/Visible spectrophotometer. Data from chart/recorder gave a graph of Absorbance against wavelength $(\mathrm{nm}) . \operatorname{Vmax}\left(\mathrm{cm}^{-1}\right)$ from IR data obtained from a Perkin Elmer FT-IR system, Spectrum BX model of IR Spectrophotometer using the $\mathrm{KBr}$ disc method also confirmed the structures. The ${ }^{1} \mathrm{H}$ NMR and ${ }^{13} \mathrm{C}$ NMR spectra of the pure compounds were determined using a $200 \mathrm{MHz}$ machine for $10 \%$ (w/v) solutions in deuterioacetone or deuteriodimethylsulphoxide using trimethylsilane (TMS) as internal standard. Pulse irradiation technique employed was FT NMR at ambient temperature. Chemical shifts are reported in ppm. Also anti-hepatotoxicity study was carried out on the ethylacetate soluble fractions of the leaves and stem bark using carbon tetrachloride induced rats.

\section{Experimental design for antihepatotoxicity study}

Rats which were bred to mature body mass were randomly assigned to eight groups with each group containing five rats $(\mathrm{n}=5)$. Animal experimental conditions are as described above. The animals were administered $100 \mathrm{mg} / \mathrm{kg}$ body mass of extracts (vehicle for the extracts was corn oil) and toxicant $\left(\mathrm{CCl}_{4}\right)$ intraperitonially. Group 1 served as control (corn oil), Group 2 $\left(\mathrm{CCl}_{4}\right.$ Only), Group $3\left(\mathrm{CCl}_{4}+\mathrm{HC}_{\mathrm{Et}}\right.$ (leaves) pre-treatment), Group $4\left(\mathrm{CCl}_{4}+\mathrm{HC}_{\mathrm{Et}}\right.$ (bark), pre-treatment), Group 5 ( $\mathrm{HC}_{\mathrm{Et}}$ (leaves)), Group $6\left(\mathrm{HC}_{\mathrm{Et}}\right.$ (bark)), Group $7\left(\mathrm{CCl}_{4}+\mathrm{KV}\right.$ pretreatment) and Group $8(\mathrm{KV})$ where $\mathrm{HC}_{\mathrm{Et}}$ is ethylacetate fraction of $H$. crepitans and $\mathrm{KV}$ is 
Kola viron (standard). $\mathrm{CCl}_{4}$ was administered 3 times in a week for two weeks. Extracts and control were administered 5 times in a week for two weeks for those without pre-treatment while those pre-treated were administered 5 times in a week for three weeks. The dose regimen and animal experimental conditions are in line with standard procedure for antihepatotoxicity screening (25-27).

\section{Biochemical Assay}

\section{Determination of haematological parameters}

The male albino rats were sacrificed by cervical dislocation after an overnight fasting. Blood samples were collected by cardiac puncture technique into clean dry centrifuge tubes and allowed to clot by standing for 30 minutes and later centrifuged at $3000 \mathrm{~g}$ for 15 minutes. The supernatant (serum) was collected and stored in the refrigerator for preservation prior to estimation of various biochemical parameters. Also collected was the liver, rinsed in ice-cold $1.15 \%$ potassium chloride $(\mathrm{KCl})$, blotted on filter paper and weighed appropriately. The liver tissues were then macerated, rinsed and homogenized in 4 volumes of homogenizing buffer ( $\mathrm{pH}$ 7.4) using a Teflon homogenizer. The homogenates were spun for 10 minutes at $10000 \mathrm{r} / \mathrm{min}$ using cold centrifuge at $4^{\circ} \mathrm{C}$. Aliquots of the supernatant obtained (the postmitochondrial fraction) was stored at $20^{\circ} \mathrm{C}$ while the liver and serum for biochemical assay were kept at ice-cold temperature.

\section{Histopathology studies}

The liver for histopathology was stored in $10 \%$ formalin and then fixed in bovine solution; processed for paraffin embedding following the standard micro technique. Sections of liver were stained with haematoxylin-eosin and were observed microscopically for any histopathological changes. Phytomicrographs of the liver samples were taken and analyzed (25-29). The following biochemical parameters: Alanine Aminotransferase (ALT), Aspartate 
Aminotransferase (AST), L- $\gamma$-Glutamyltransferase (GGT), Urea and Creatinine (CREA) were assayed on the serum according to the methods described in the kits manufactured by Randox Laboratories Ltd, United Kingdom. In ALT determination, $\alpha$ - oxoglutarate reacted with Lalanine to give L-glutamate and pyruvate and ALT was measured by monitoring the concentration of pyruvate hydrazone formed with the 2, 4-dinitrophenylhydrazine. Transaminase activities in some sera were stimulated by high concentrations of aldehydes, ketones or oxo acids. Measurement against a serum blank instead of a reagent blank eliminated this effect. Also for AST determination, $\alpha$ - oxoglutarate reacted with L-aspartate to give L-glutamate and oxaloacetate, AST was measured by monitoring the concentration of oxaloacetate hydrazone formed with 2, 4-dinitrophenylhydrazine. L- $\gamma$-Glutamyltransferase $(\gamma$-GT/GGT) however, involved a reaction of L- $\gamma$-glutamyl-3-carboxy-4-nitroanilide with glycylglycine in the presence of $\gamma$-GT to give L- $\gamma$-glutamylglycylglycine and 5-amino-2nitrobenzoate. CREA, in alkaline solution reacted with picric acid to form a colored complex. The amount of the complex formed was directly proportional to the creatinine concentration and was so determined. Lastly, Urea in serum was hydrolyzed to ammonia in the presence of urease. Ammonia was then measured photometrically by the Berthelot's reaction (30).

\section{Determination of protein}

Protein concentration of the various samples was determined by means of the Biuret method as described by Gornal et al., (1949) (31) with some modification. Biuret reagent contained $\mathrm{CuSO}_{4}$, KI and potassium sodium tartarate $\left(\mathrm{KNaC}_{4} \mathrm{H}_{4} \mathrm{O}_{6} \cdot 4 \mathrm{H}_{2} 0\right)$. Proteins form a coloured complex with cupric ions $\left(\mathrm{Cu}^{2+}\right)$ in an alkaline solution. Potassium iodide (KI) was added to the reagent in order to prevent the precipitation of $\mathrm{Cu}^{2+}$ ions as cuprous oxide. 


\section{Procedure for Protein Determination in the samples}

The post mitochondrial fractions of the supernatants were diluted 5 times with distilled water so as to increase the sensitivity range of Biuret method. Diluted sample $(1 \mathrm{ml})$ was added to 3 $\mathrm{ml}$ of Biuret reagent. The mixture was incubated at room temperature for $30 \mathrm{~min}$ after which the absorbance was read at $540 \mathrm{~nm}$ using distilled water as blank. The protein content of the samples was extrapolated from the standard Bovine Serum Albumin (BSA) curve (29-31).

\section{Data analysis}

Graphs were plotted from the experiment carried out and Absorbance Vs U/I values given in the kit served as the calibration curve. ALT, AST, GGT, Urea and CREA activities in the serum were then obtained by extrapolation from the graph. The mean value \pm SEM was calculated for each parameter and analyzed separately using ANOVA followed by Dunnets ' $\mathrm{t}$ ' test.

\section{RESULTS AND DISCUSSION}

Secondary plant metabolites

Secondary metabolites found in H. crepitans leaves and stem bark extracts were alkaloids, flavonoids, tannins, steroids and phenolic compounds. Five pure compounds were obtained and recrystallized but four were fully characterized. They are daphnetoxin acid, huratoxin, apocynin and methylpentadecanoate. Daphnetoxin; a daphnane diterpene and apocynin though are known compounds are newly reported in $H$. crepitans. These compounds were identified by their UV, IR, ${ }^{1} \mathrm{H}$ and ${ }^{13} \mathrm{C}$ - NMR. The spectra data obtained are in complete agreement with literature values. Structures of the compounds reported here are shown in Fig. 1. 
1-(4-hydroxy-3-methoxyphenyl) ethanone (Apocynin; Acetovanillone) (Ola 1): UV [EtOH]nm (log $\varepsilon): 264$ (0.423), 301 (0.162); IR (KBr) $\mathrm{V}_{\max } \mathrm{cm}^{-1}: 3440.21(\mathrm{O}-\mathrm{H}), 1750.14$

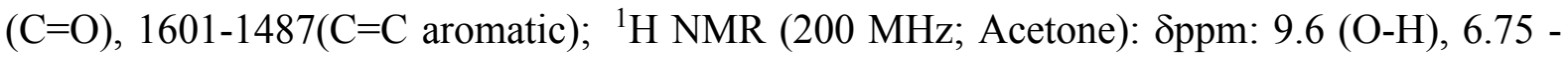
$7.9\left(3 \mathrm{H}, \mathrm{m}\right.$, aromatic), $3.2-4.6\left(3 \mathrm{H}, \mathrm{OCH}_{3}\right), 2.6\left(3 \mathrm{H}, \mathrm{CH}_{3}\right),{ }^{13} \mathrm{C} \mathrm{NMR}(50 \mathrm{MHz}$, Acetone $) \delta$ ppm: $206.2(\mathrm{C}=\mathrm{O}), 104.0\left(\mathrm{C}\right.$-unsaturated ring system), $58.6\left(\mathrm{O}-\mathrm{CH}_{3}\right), 28\left(\mathrm{CH}_{3}\right)$; Molecular formulae: $\mathrm{C}_{9} \mathrm{H}_{10} \mathrm{O}_{3}$, Mpt $112-115^{\circ} \mathrm{C}$.

Huratoxin (Ola 2): UV [EtOH]nm (log ع): 290.65 (0.257), IR (KBr) $\mathrm{V}_{\max } \mathrm{cm}^{-1}: 3433.26$ (OH), $2928.72(\mathrm{C}-\mathrm{H}), 1653.97(\mathrm{C}=\mathrm{O}), 1508.13$ (C=C alkene), 1458.02 (C-H bending), 1261.68 (C-O alcohol), 1024.37 (C-O ether), 995.46 (C-H, ring), 827.00 - 632.26 and 383.39-370.49 (fingerprint region, $\mathrm{C}-\mathrm{H}$ aliphatic , $\mathrm{C}-\mathrm{O}, \mathrm{C}-\mathrm{C}) ;{ }^{1} \mathrm{H}$ NMR (200 MHz; DMSO): $\delta p p m: ~ 8.8$ (1H, m, cycloalkene,H-1), 6.6-7.3 (3H, m, OH), 5.2-5.5 (6H, m, alkene) 3.3-4.2 (10H, m, cyclic), 0.4-2.8 (28H, m, polymethylene $\mathrm{CH}_{2} /$ terminal $\left.\mathrm{CH}_{3}\right) ;{ }^{13} \mathrm{C} \mathrm{NMR}(50 \mathrm{MHz}, \mathrm{DMSO}) \delta$ ppm: 207.190 (C-3, C=O), 177.275(C-1), 174.933 (C-15), 172.473 (C-2),145.984 (C-3'), 145.823 (C-4'), 138.839 (C-5'), 109.173(C-12), 108.968 (C-16), 79.259 (C-8), 77.472(C-2'), 56.387(C9,13,14, 3 C-O, bridged), 53.356 (C-4,5,20, 3C-O, (OH)), 51.921 (C-6, 7), 36.649(C-10), 32.974(C-11), 30.602(C-18), 30.206(C-17), 29.825-24.935 (C-6' - 13'), 19.019(C-1'), 18.814(C-19), 14.451-14.012 (C-14') Molecular formulae $\mathrm{C}_{34} \mathrm{H}_{48} \mathrm{O}_{8}$, Mpt 217$219^{0} \mathrm{C}$

Daphnetoxin acid (Ola 3): UV [EtOH]nm (log $\varepsilon): 295.07(0.257)$; IR (KBr) $\mathrm{V}_{\max } \mathrm{cm}^{-1}$ : 3400.14 (O-H stretch, broad), $2907.06(\mathrm{C}-\mathrm{H}$, saturated), 1712.97(C=O), and $1508.13(\mathrm{C}=\mathrm{C})$, 1475.02 (C-H bending), 1361.68 (C-O, alcohol), 1234.37 (C-O, ether), 995.46, 827.00,

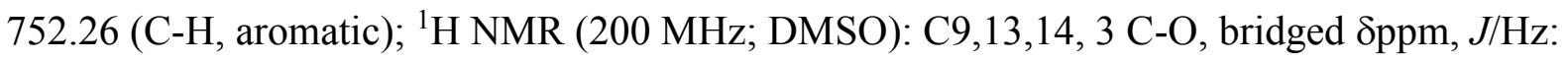
$12.85\left(\mathrm{OH}\right.$, carboxylic acid), $7.763\left(5 \mathrm{H}\right.$, cycloalkene), $6.104\left(\mathrm{CH}_{2}\right.$, ethylene, cyclopentene), 4.6 - $3.8(\mathrm{OH}$, alcohol), 3.653- $3.362(\mathrm{H}$, methine, cyclopentene, cyclohexane), 2.913 - 
2.491(H, oxiran, saturated ring system), 1.589-1.137 (H, methyl); ${ }^{13} \mathrm{C} \mathrm{NMR}(50 \mathrm{MHz}$, DMSO) $\delta$ ppm:, 173.146 (C=O, C-21), 171.301(C-2'), 162.530 (C-15), 150.143(C-2), 144.872 (C-3'), 136.994(C-7'), 136.291(C-5'), 135.398(C-4'), 135.427(C-6'), 132.859(C-1), 128.984(C-1'), 128.736(C-16), 123.054(C-13), 104.429 (C-9), 97.152(C-14), 94.252(C-6), 89.069(C-7), 52.639(C-20), 51.277 (C-5), 40.763(C-4), 39.928(C-11), 39.519(C-12), 38.584(C-3), 38.260(C-8), 22.534(C-10), 17.305(C-19), $11.903(\mathrm{C}-17), 10.556$ (C-18) Molecular formulae: $\mathrm{C}_{28} \mathrm{H}_{32} \mathrm{O}_{9}$, Mpt $193-196^{\circ} \mathrm{C}$.

Ola 4 is a dark brownish solid substance; UV [EtOH]nm (log $\varepsilon): 290.65$ (0.38125); IR (KBr) $\mathrm{V}_{\max } \mathrm{cm}^{-1}: 3399.29(\mathrm{O}-\mathrm{H}$ stretch, broad), $1700.18(\mathrm{C}=\mathrm{O}), 1653.82-1507.35(\mathrm{C}=\mathrm{C}), 1457.81$ (C-H, bend), 1030.85 (C-O), 665.89, 432.89, 373.41, 361.91(fingerprint region, $\mathrm{C}-\mathrm{H}$ aliphatic , $\mathrm{C}-\mathrm{O}, \mathrm{C}-\mathrm{C})$. No enough data to characterize it but chemical test confirmed it was a flavonoid.

Methylpentadecanoate (Ola 5): dark brownish solid; UV [EtOH]nm (log \&): 300.34 (0.374); IR (KBr) $\mathrm{V}_{\max } \mathrm{cm}^{-1}: 2914.08(\mathrm{C}-\mathrm{H}), 1710.02(\mathrm{C}=\mathrm{O}), 1076.23(\mathrm{C}-\mathrm{O}),{ }^{1} \mathrm{H}$ NMR (200 MHz; DMSO): $\delta p p m, J / H z: 3.2-3.6\left(3 \mathrm{H}, \mathrm{s},-\mathrm{CH}_{3}-\mathrm{O}\right), 2.5\left(2 \mathrm{H}, \mathrm{s},-\mathrm{COCH}_{2}-\right), 0.8-1.6\left({ }^{-} \mathrm{CH}_{3^{-}}\right.$, Aliphatic $-\mathrm{CH}_{2}$ - unresolved sharp singlet). ${ }^{13} \mathrm{C}$ NMR; ATP (50MHz, DMSO) $\delta$ ppm: 191.303 $(\mathrm{C}=\mathrm{O}), 53.4\left(\mathrm{OCH}_{3}\right), 29.474-38.750\left(-\mathrm{CH}_{2}-\right), 15.7\left(\mathrm{CH}_{3}\right)$; Molecular formulae $\mathrm{C}_{16} \mathrm{H}_{32} \mathrm{O}_{2}$, Mpt $18-20^{\circ} \mathrm{C}$.

Spectroscopic studies showed that the compounds were unsaturated; The UV absorption values above $260 \mathrm{~nm}$ obtained for these compounds falls into the range for cyclic compounds. Transition in $270-350 \mathrm{~nm}$ is $n-\pi^{*}$ transition of ketones. IR spectrum displayed characteristic absorptions for signals due to $\mathrm{OH}, \mathrm{C}=\mathrm{C}, \mathrm{C}=\mathrm{O}, \mathrm{C}-\mathrm{O}$ functional groups. Oxygen function group with signals of aromatic hydrogen in the ${ }^{1} \mathrm{H}$ NMR was observed typical of aryl hydrogen adjacent to oxygen functions. These data are in complete agreement with those reported for these compounds in literature (32-33). 
Apocynin or acetovanillone is an organic compound found in natural source and has been reported to have pharmacological activities (33). It is however newly reported in $H$. crepitans and was obtained as a dark green solid. Absorption peaks for $\mathrm{OH}$ at $3440.21 \mathrm{~cm}^{-1}$ and $1750.14 \mathrm{~cm}^{-1}$ for $\mathrm{C}=\mathrm{O}$ were prominent in the IR region. The ${ }^{1} \mathrm{H}$ NMR revealed that it has aromatic group (6.7-7.9 ppm), ether/hydroxy/ketone group (3.2-4.6 ppm) and methylene group (2.6 ppm). The ${ }^{13} \mathrm{C}$ NMR revealed the presence of carbonyl function at $206 \mathrm{ppm}$.

Huratoxin was also obtained as a dark greenish solid. It is a piscicidal compound (widely used to catch fish in different parts of the world) and had been isolated from the milky sap of $H$. crepitans. Prominent peaks corresponding to $\mathrm{OH}\left(3433.26 \mathrm{~cm}^{-1}\right), \mathrm{C}-\mathrm{H}$ $\left(2928.72 \mathrm{~cm}^{-1}\right), \mathrm{C}=\mathrm{C}$ ring $\left(2129.23 \mathrm{~cm}^{-1}\right), \mathrm{C}=\mathrm{O}\left(1653.97 \mathrm{~cm}^{-1}\right)$ were observed but absorption for $\mathrm{C}=\mathrm{O}$ was unusually low because $\mathrm{C}=\mathrm{C}$ bond adjacent to a carbonyl group results in the delocalization of the $\pi$ electrons in the $\mathrm{C}=\mathrm{O}$ and $\mathrm{C}=\mathrm{C}$ bonds resulting in the lowering of the frequencies. The ${ }^{1} \mathrm{H}$ NMR revealed absorption peaks at $\delta(\mathrm{ppm})$ 6.6-7.3 and 0.4-2.8 due to free $\mathrm{OH}$ and polymethylene $\left(\mathrm{CH}_{2} /\right.$ terminal $\left.\mathrm{CH}_{3}\right)$ respectively; ${ }^{13} \mathrm{C}$ NMR showed prominent peaks due to $\mathrm{C}=\mathrm{O}$ at $\delta(\mathrm{ppm}) 207.190$ and $\mathrm{C}-\mathrm{O}$ at 56.387- 51.921. About fourteen isomers of this compound are known to exist (11-13).

Daphnetoxin is a benzoic acid-ortho ester of a diterpenoid and contained carbonyl, aromatic, hydroxy/ether and methylene/alkyl groups. Acid displacement of the cyclopentenone functional group was observed in the IR $\mathrm{V}_{\max } \mathrm{cm}^{-1}: 3400.14$ for O-H stretch, 2907.06 due to $\mathrm{C}-\mathrm{H}$ (saturated) and $1712.97(\mathrm{C}=\mathrm{O})$. Signals in the ${ }^{1} \mathrm{H}$ NMR at $\delta p p m: 12.85$ due to $\mathrm{OH}$ of a carboxylic acid and $2.913-2.491$ due to proton of a saturated ring system, oxiran; data from ${ }^{13} \mathrm{C}$ NMR $\delta(\mathrm{ppm})$ further confirmed the structure, $\mathrm{C}=\mathrm{O}$ at 173.146 and $\mathrm{C}$ $\mathrm{O}$ at $52.639-51.277$.

Methylpentadecanoate is an ester. Prominent peaks due to $\mathrm{C}-\mathrm{H}$ at 2914.08 and $\mathrm{C}=\mathrm{O}$ at 1710.02 were observed in the IR spectrum. The ${ }^{1} \mathrm{H}$ NMR displayed characteristics resonance 
peaks in the aliphatic region. Protons in three different environments were observed. The presence of methyl proton signal next to an ester group at 2.9-3.6 ppm, methylene protons next to a carbonyl was observed at 2.1-2.7 ppm while the terminal protons of a methyl group and other methylene protons were accounted for by signals observed at 0.8-1.2 ppm. The attached proton test experiment (ATP) revealed the presence of quaternary carbonyl carbon at 191.303 ppm and saturated carbon; methylene and methyl groups without electronegative element at 29.474 while peak at $41.247 \mathrm{ppm}$ was assigned to saturated carbon attached to an electronegative atom $(\mathrm{C}-\mathrm{O})$. The presence of this ester was accounted for as a break down product from the side chain of the daphnane diterpene isolated in the compound. Daphnane diterpenes with a tricycle [9.3.0] tetradecane ring system have been isolated from the extracts of sap and seeds of Euphorbiaceae plants. Some of these compounds have been shown to exhibit cytotoxic, irritant, and analgesic activity (15-18, 23, 33-34).

\section{Hepatoprotective activity}

Carbon tetrachloride $\left(\mathrm{CCl}_{4}\right)$ is a hepatotoxin commonly used for the production of experimental liver toxicity or damage (34-37). Assessment of liver function is done by estimating the activities of CREA and Urea as well as that of serum marker enzymes like ALT, AST, GGT $(22,25-27)$. When liver cell plasma membrane is damaged, a variety of enzymes normally located in the cytosol are released into the blood stream. Their estimation in the serum is a useful quantitative marker of the extent and type of hepatocellular damage (38-40). In this present study, it was revealed that the ethylacetate extracts induced suppression of increased activities of the enzymes ALT, AST, GGT, as well as Urea and CREA (which are nitrogenous waste products excreted from the body) when compared to the $\mathrm{CCl}_{4}$ group $(P<0.05)$. Table 1 shows the effect of ethylacetate fractions of leaves and stem bark of $H$. crepitans on different biochemical parameters in the serum of 
rats. There was a significant increase in ALT and AST levels $(\mathrm{P}<0.05)$ in group $2\left(\mathrm{CCl}_{4}\right.$ only $)$ when compared to other groups (control, $\mathrm{CCl}_{4}+$ leaves extract, $\mathrm{CCl}_{4}+$ bark extract, leaves extract only, bark extract only, $\mathrm{CCl}_{4}+$ kolaviron and kolaviron only). The observed increase can be attributed to the release of these enzymes from the liver into the serum indicating hepatotoxin effect of $\mathrm{CCl}_{4}$. The co-administration of $\mathrm{CCl}_{4}$ and the extracts as well as the standard kolaviron at $200 \mathrm{mg}$ extract/kg animal body weight in groups 3,4 and 7 brought about a decrease in the ALT and AST activity indicating that the extracts reduced the effect of tetrachloride exposure on both biochemical parameters. There was also significant decrease in ALT level $(\mathrm{P}<0.05)$ in group 1 (control) when compared to group 6 (bark extract), group $7\left(\mathrm{CCl}_{4}+\right.$ kolaviron) and group 8 (kolaviron) indicating that there was no kidney impairment. Gamma-glutamyltransferase (GGT) is elevated in all forms of liver disease like liver cancer or cirrhosis and originates primarily from the hepatobiliary system. There was significant increase in GGT level $(\mathrm{P}<0.05)$ in group $2\left(\mathrm{CCl}_{4}\right.$ only) when compared to other groups indicating that the toxicant was able to induce liver diseases. GGT level however decreased in the other groups indicating protection (Table 1). The toxic metabolite $\mathrm{CC}_{3}$ radical was produced by cytochrome $\mathrm{P} 450$ which further reacts with oxygen to produce trichloromethyl peroxy radicals. These radicals bind covalently with the macromolecule and cause peroxidative degradation of lipid membrane of the liver. Alanine aminotransferase (ALT) and aspartate aminotransferase (AST) are members of transaminase (aminotransferase) family of enzymes and facilitate certain chemical reactions within the cells. ALT is majorly found in the liver while AST is found in the liver, kidney and brain. When cells are injured or necrosis occurs, enzymes such as ALT, AST, GGT are released from the cells into the blood stream to protect the cell organs against the damage. Urea and CREA (nitrogenous waste products excreted from the body in the urine) levels also increased. The determination of these transaminases in the serum is therefore often used as one of the essential makers of 
the cells functionality. Thus, the reduction of ALT, AST, GGT, Urea and CREA activities by the extracts is an indication of repair of hepatic tissue damage induced by $\mathrm{CC}_{4}$ and that serum transaminases returned to normal activities with the healing of hepatic parenchyma and regeneration of hepatocytes (41).

Creatinine and urea which are nitrogenous waste products excreted from the body in the urine via the kidney are used exclusively in the assessment of the kidney function. Elevation of creatinine and urea is indicative of kidney impairment. There was no significant increase in creatinine $(\mathrm{P}>0.05)$ when group $2\left(\mathrm{CCl}_{4}\right)$ and group 1 (control) were compared with other groups but there was significant increase in urea level $(\mathrm{P}<0.05)$ in group $2\left(\mathrm{CCl}_{4}\right.$ only) when compared to other groups. The observed increase can be attributed to the release of urea from the kidney into the blood stream indicating nephrotoxin effect of the toxicant. The effect was reduced by co-administration with the extracts. Thus, administration of ethylacetate fractions of $H$. crepitans leaves and stems bark gave hepatoprotective activity against the toxic effect of $\mathrm{CCI}_{4}$, which is also supported by histological studies. Also lack of variation in protein concentration of the various samples as determined by the Biuret method showed that there was no significant increase $(\mathrm{P}>0.05)$ in group 2 (toxicant only) when compared with other groups (Table 1).

\section{Comparative histopathology studies of livers from different groups}

A comparative histopatological study of liver from the groups further corroborated the hepatoprotective effect of $H$. crepitans. Histopathology of liver from normal control group shows prominent central vein, normal arrangement of hepatic cells. Microscopical examination of carbon tetrachloride treated liver section showed various degrees of pathological changes starting from centrilobular necrosis of hepatic cells and central lobular fatty regeneration. Photomicrographs of the liver samples are shown Fig $2.1-2.8$. 
Histopathological studies revealed that group 1 control animals showed normal hepatocytes (Fig 2.1), group $2\left(\mathrm{CCl}_{4}\right.$ treated) showed periportal hepatic necrosis /cellular infiltration (mild), bile duct hyperplasia (Fig 2.2) and also exhibited intense centrilobular necrosis, vacuolization and macrovesicular fatty change, group $3\left(\mathrm{CCl}_{4}+\right.$ leaves extract) and group 4 $\left(\mathrm{CCl}_{4}+\right.$ bark extract $)$ showed mild periportal hepatic necrosis/cellular infiltration and moderate bile duct hyperplasia (Fig 2.3 and 2.4), group 5 (leaves extract only) and group 6 (bark extract only) showed no visible lesions (Fig 2.5 and 2.6), group $7\left(\mathrm{CCl}_{4}+\right.$ kolaviron) (Fig 2.7) had normal arrangement of hepatic cells while group 8 (kolaviron only) showed very mild ventral venous congestion (Fig 2.8). Thus, the animals treated with ethylacetate fractions of leaves and stem bark of $H$. crepitans exhibited significant liver protection against the toxicant as evident by the presence of normal hepatic cords, absence of necrosis and lesser fatty infiltration. The present histopathological and biochemical studies of the ethylacetate fraction of $H$. crepitans confirm its medicinal application as hepatoprotective agent in traditional herbal practise. There were also indications that the presence of daphnane diterpenes in $H$. crepitans may have played a major role in the observed activity however the pure compounds must be subjected to hepatoxicity study.

\section{CONCLUSION}

Spectroscopic analysis of the pure compounds obtained from ethyl acetate and butanol fractions of $H$. crepitans leaves and stem bark using UV-Visible, Infrared, ${ }^{1} \mathrm{H}$ and ${ }^{13} \mathrm{C}-\mathrm{NMR}$ revealed the presence of carbonyl, hydroxyl, aromatic alkene and methylene functional groups in the pure compounds. These compounds namely daphnetoxin acid, huratoxin, apocynin and methylpentadecanoate were reported. The result of the hepatoprotective activity revealed that the ethyl acetate soluble fractions of $H$. crepitans leaves and stem bark 
showed significant hepatoprotective activity by reducing elevated levels of serum enzymes, ALT, AST, GGT, as well as Urea and CREA levels. A comparative histopathological study of the liver from different group further corroborated the hepatoprotective efficacy of $H$. crepitans as it showed a significant regeneration of hepatocytes. This present study has therefore been able to establish the hepatoprotective influence of the leaves and stem bark of H. crepitans and secondary plant metabolites of medicinal importance have been isolated. However, more in vivo assays are also essential to characterize them as biological hepatoprotective agents. Additional work is also necessary to subject the pure isolated compounds from ethylacetate soluble fractions to hepatoprotective activity to know the isolates that are responsible for the observed activity in this promising plant.

\section{ACKNOWLEDGEMENTS}

The authors would like to thank the MacArthur Foundation for the award of a Start-up Research Grant (2010 Grants) tenable at the University of Ibadan, Nigeria to G.K. Oloyede in respect of this work. The staff of Multi Research Central Science Laboratory, University of Ibadan and Central Science Laboratory Obafemi Awolowo University Ile-Ife, Osun State are also gladly acknowledged for the use of spectroscopic equipment. Our appreciation also goes to the staff of the Bio-membrane Research Laboratory, Department of Biochemistry, University of Ibadan, Nigeria for assisting in carrying out the hepatoprotective assay. 


\section{REFERENCES}

1. Hamburger M, Hostettman K. Bioactivity in Plants: The link between phytochemistry and medicine. Phytochemistry 1991; 30: 3864-74.

2. Simson BB, Ogorzaly MC. Economic Botany Plants In Our World. USA. McGrawHill, Inc 1995; 742-80.

3. Yue-Zhong Shu. Recent natural products based drug development: A pharmaceutical industry perspective. J Nat Prod 1998; 61: 1053-71.

4. Ayuveda JP, Verpoorte R. Some Phytochemical aspects of medicinal plants research. J Ethnopharmacol 2005; 25: 43-59.

5. Calixto JB. Efficacy, Safety, quality control, marketing and regulatory guidelines for herbal medicines (Phytotherapeutic agents). Braz J Med Biol Res 2000; 33: 179-90.

6. Cragg GM, Newmann DJ, Snader KM. Natural Products in drug discovery and development J Nat Pro 1997; 60: 52-60.

7. De Pasquale A. Pharmacognosy: The oldest modern science. J Ethnopharmacol 1984; 11: $1-16$.

8. Vulto AG, Smet PA. Meyler's side effects of Drugs (11th ed). In: Dukes, M.M.G., editor, 1988. Elsevier, Amsterdam, 1988; 999-1005.

9. Burkill HM. The Useful Plant of West Tropical Africa, Vol $12^{\text {nd }}$ Edition, Royal Botanical Garden Kew. 1994; 850-950.

10. Adedire CO, Ajayi OE. Potential of Sandbox oil for the protection of Cowpea seeds. Food Chem 2003; 110: 602-5.

11. Jaffé, WG. A new plant protease from Hura crepitans. Biochem 1943; 148: 184-8.

12. Jaffé WG. Seidi DS. Crepitin, a phytohemaglutinin from Hura crepitans Cellular and Mol Life Sci J 1969; 25 (8): 891-2 DOI: 10, 1007/BF01897942 
13. Kawazu K. Active constituents of Piscicidal plants. Biochem 1972; 30: 615-28.

14. Wehner QP, Swaine MD, Beer T. Explosive seed dispersal in Hura crepitans L. (Euphorbiaceae). New phytologist 1931; 78: 695-708.

15. Barbieri L, Falasca A, Franceschi C, Licastro F, Rossi CA. Stirpe F. Purification and properties of two lectins from the latex of the Euphorbiaceous plants Hura crepitans L. (sand-box tree) and Euphorbia characias L. (Mediterranean spurge) Biochem J 1983; 215: 433-9.

16. Fowomola MA, Akindahunsi AA. Nutritional Quality of Sandbox tree. J Med Food 2007; 10: 159-64.

17. Oderinde RA, Ajayi RA, Adewuyi A. 2009a . Characterisation of seed and seed oil of Hura crepitans and the Kinetics of Degradation of the oil during heating. Electronic J Environment, Agric and Food Chem. 8: 201-8.

18. Oderinde RA., Ajayi RA., Adewuyi A. 2009 . Preliminary Toxicological Evaluation and Effect of the Seed oil of Hura crepitans and Blighia unijugata Bak on the lipid profile of Rat. Electronic J Environment, Agric and Food Chem. 8(3): 209-17.

19. Lasisi AA, Folarin MO, Balogun SA, Adebisi SA. Phytochemicals from the root of Hura crepitans (Euphorbiaceae) and Antibacterial Potency. Proceedings of the Chemical Society of Nigeria (CSN) $34^{\text {th }}$ Annual International Conference $2011 ; 138$ 143.

20. Oloyede GK, Olatinwo MB. In vitro antioxidant activity of extracts from the leaves of Hura crepitans (Euphorbiaceae) - a comparison of two assay methods. Cell Membranes and Free Rad Res J 2011; 3(1): 133-8.

21. Oloyede GK, Olatinwo MB. Phytochemical investigation, toxicity and antimicrobial screening of essential oil and extracts from leaves and stem bark of Hura crepitans (Euphorbiaceae) Academia Arena 2014; 6(5): 7-15. 
22. Oloyede GK, Onocha PA, Adaramoye OA, Thonda ES. Hepatoprotective activity and flavonoids of Alchornea lax flora Leaves Extract Res J Phytochem 2011; 5(4): 190200.

23. Sharma A, Chakraborti KK, Handa SS. Anti-hepatotoxic activity of some Indian herbal formulations as compared to silymarin. Fitoterapia 1991; 62:229-235.

24. Subramonium A, Pushpangadan P. "Development of Phytomedicines for liver diseases”. Indian J Pharmacol, 1999; 31: 166-75.

25. Recknagel RO. "A new direction in the study of carbon tetrachloride hepatotoxicity". Life Sci. 1983; 33: 401-408.

26. Chattopadhyay RR. Possible mechanism of hepatoprotective activity of Azadirachta indica leaf extract. Part II. J Ethnopharmacol 2003; 89: 217-9.

27. Mankani KL, Krishna V, Manjunatha BK, Vidya SM, Jadadeesh SD. Evaluation of hepatoprotective activity of stem bark of Pterocarpus marsupium Roxb. Indian J Pharmacol 2005; 37: 165-8.

28. Avijeet J, Manish S, Lokesh D, Anurekha J, Rout SP, Gupta VB et al. Antioxidant and Hepatoprotective activity of Ethanolic and Aqueous extracts of Momordica dioica roxb leaves. J Ethnopharmacol 2008; 115: 61-6.

29. Said SM, Husein KH. Hepatoprotective effect of Cinnamon extracts against carbon tetrachloride induced oxidative stress and liver injury in rats, Biol Res 2009; 42: 93-8.

30. Smna KA. Colourimetric assay of catalase. Analytical Biochem 1972; 47: 389-94.

31. Gornal AG. Determination of Serum protein by means of the Buiret reaction. J. Biol Med 1949; 27: 751-766.

32. Seidl DS, Jaffe GW. Comparative action of Hurain and Trypsin on Native and denatured proteins, Dept. de Bioquimica, Fac. de Ciencias, Univ. Central, Caracas, Venezuela Bulletin 1967; 1-7. 
33. Palmen MJHJ., Beukelman CJ, Mooij RGM, Pena AS, Van Rees EP. Antiinflammatory effect of apocynin, a plant derived NADPH oxidase antagonist, in acute experimental colitis. The Netherlands J of Med 1995; 47(2): 41-47.

34. James GWL, Pickering RW. The protective effect of a novel compound RU-18492 on galactosamine induced hepaptotoxicity in rats. Drug Res 1976; 26: 2197-9.

35. Recknagel RO, Glende RA, Hruszkewycz AM. "In: Pryor, E. A. Jr. (Ed.), Free Radicals in Biology” Vol. II. Academic Press, NY. 1976; 97-132.

36. Thabrew MI, Joice PD, Rajatissa WA. Comparative study of efficacy of Paetta indica and Osbeckia octandra in the treatment of liver dysfunction. Planta Medica 1987; 53: $239-41$.

37. Md. Rajib A, Km Monirul I, Israt JB, Md. Ashik M, Ekramul H. Hepatoprotective Activity of Methanol Extract of Some Medicinal Plants Against Carbon Tetrachloride-Induced Hepatotoxicity in Rats. European J Sci Res 2009; 37: 302-10.

38. Wolf CR, Harrelson WG. Jr, Nastainczyk WM, Philpot RM, Kalyanaraman B, Mason RP. Metabolism of carbon tetrachloride in hepatic microsomes and reconstituted monooxygenase systems and its relationship to lipid peroxidation. Molecular Pharmacol. 1980; 18: 553-8

39. Ward FM., Daly MJ. "Hepatic Disease. In: Clinical Pharmacy and Therapeutics (Walker R .and C. Edwards Eds.)”. Churchill Livingstone, New York. 1999; 195-212.

40. Venukumar MR., Latha J. Hepatoprotective effect of the methanolic extract of Curculigo orchioides in $\mathrm{CCl}_{4}$-treated male rats. Indian J Pharmacol 2002; 34: 269-75.

41. Recknagel RO, Glende EA. Jr. "Carbon tetrachloride hepatotoxicity: an example of lethal cleavage". Crit Rev Toxicol 1973; 2: 263-297. 
Table 1: Effect of Ethyl acetate fractions of leaves and stem bark of Hura crepitans on different biochemical parameters in the serum of rats measured in absorbance units (AU)

\begin{tabular}{|c|c|c|c|c|c|c|c|}
\hline \multirow[b]{2}{*}{ Group } & \multirow[b]{2}{*}{ Treatment } & \multicolumn{6}{|c|}{ Serum parameters } \\
\hline & & ALT & AST & GGT & Urea & Creatinine & Protein \\
\hline 1. & $\begin{array}{l}\text { Control } \\
\text { (corn oil) }\end{array}$ & $83.3 \pm 7.37 * *$ & $37.3 \pm 9.45 * *$ & $3.09 \pm 3.34 * *$ & $8.85 \pm 3.07 * *$ & $49.71 \pm 8.28$ & $10.17 \pm 1.04$ \\
\hline 2. & $\mathrm{CCl}_{4}$ & $105.0 \pm 0.001 *$ & $100.0 \pm 15.0 *$ & $8.69 \pm 7.47 *$ & $13.38 \pm 2.89 *$ & $53.85 \pm 7.18$ & $9.87 \pm 1.44$ \\
\hline 3. & $\begin{array}{l}\mathrm{CCl}_{4}+\mathrm{HC}_{\mathrm{Et}} \\
\text { (leaves) }\end{array}$ & $78.3 \pm 6.56^{* *}$ & $45.3 \pm 9.87 * *$ & $8.42 \pm 6.55 * *$ & $3.52 \pm 0.81^{*, * *}$ & $52.2 \pm 4.39$ & $9.00 \pm 0.01$ \\
\hline 4. & $\begin{array}{l}\mathrm{CCl}_{4}+\mathrm{HC}_{\mathrm{Et}} \\
\text { (bark) }\end{array}$ & $70.0 \pm 6.56^{* *}$ & $60.0 \pm 19.08^{* * * *}$ & $8.39 \pm 7.47 *, * *$ & $5.79 \pm 1.39 * *$ & $65.25 \pm 21.97$ & $8.88 \pm 0.63$ \\
\hline 5. & $\begin{array}{l}\mathrm{HC}_{\mathrm{Et}} \\
\text { (leaves) }\end{array}$ & $69.0 \pm 13.23 * *$ & $37.0 \pm 8.89 * *$ & $6.66 \pm 7.64 * *$ & $6.06 \pm 0.48 * *$ & $54.38 \pm 20.53$ & $8.67 \pm 0.29$ \\
\hline 6. & $\mathrm{HC}_{\mathrm{Et}}$ (bark) & $53.3 \pm 2.52 *, * *$ & $47.5 \pm 0.71 * *$ & $3.47 \pm 1.16^{* *}$ & $8.29 \pm 0.11 * *$ & $64.21 \pm 9.49$ & $9.17 \pm 0.29$ \\
\hline 7. & $\mathrm{CCl}_{4}+\mathrm{KV}$ & $63.7 \pm 4.73 * * *$ & $49.0 \pm 1.41 * *$ & $2.32 \pm 0.001 * *$ & $6.48 \pm 0.40 * *$ & $43.50 \pm 10.76$ & $9.00 \pm 0.50$ \\
\hline 8. & $\mathrm{KV}$ & $60.0 \pm 8.19 *, * *$ & $27.5 \pm 9.19 * *$ & $2.89 \pm 0.81 * *$ & $5.87 \pm 2.38 * *$ & $43.50 \pm 0.001$ & $8.00 \pm 2.02$ \\
\hline
\end{tabular}

$*=$ The mean difference is significant at $\mathrm{P}<0.05$ when compared with the control.

$* *=$ The mean difference is significant at $\mathrm{P}<0.05$ when compared with the toxicant $\left(\mathrm{CCl}_{4}\right)$.

$\mathrm{KV}=$ Kola viron, $\mathrm{Et}=$ ethylacetate, $\mathrm{CCl}_{4}=$ carbon tetrachloride. 


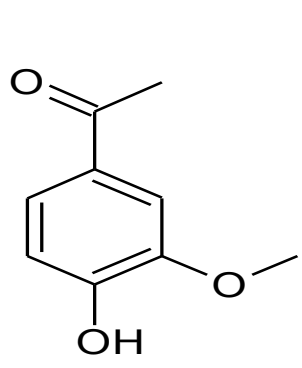

(i)

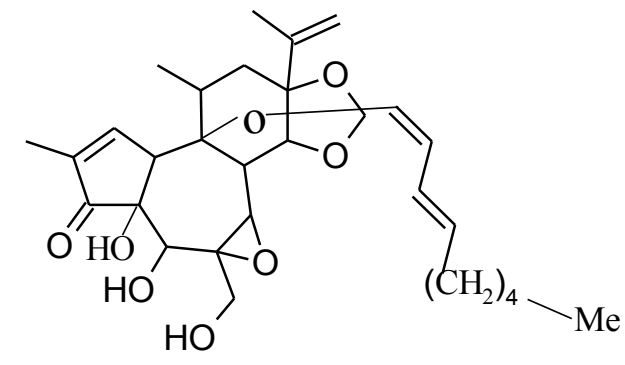

(ii)

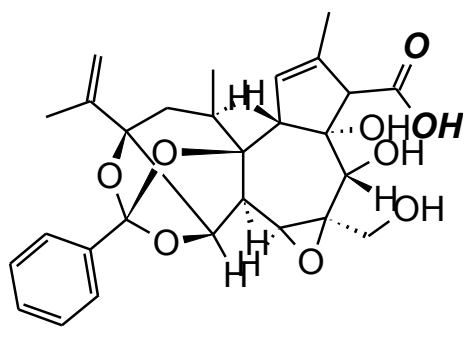

(iii)<smiles>CCCCCCCCCCCCCCC(=O)OC</smiles>

(iv)

Fig 1: Structures of (i) Apocynin, (ii) Huratoxin, (iii) Daphnetoxin acid and (iv) methylpentadecanoate.

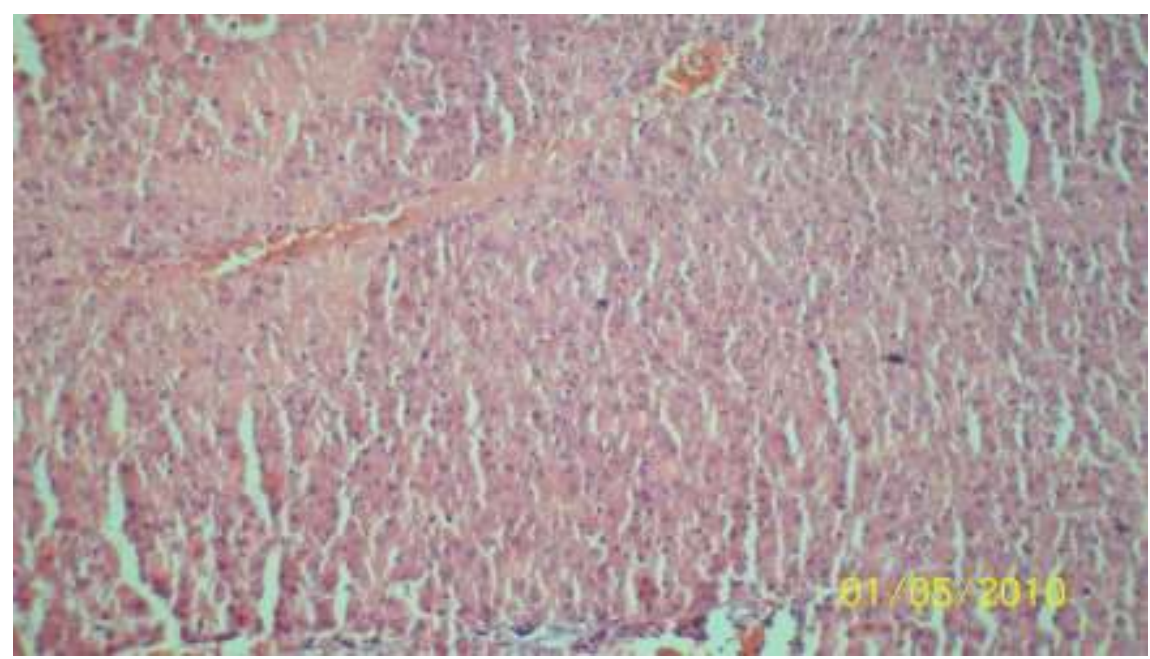

Fig 2(a): Liver section from group 1 (control/corn oil) showing normal histology, prominent central vein with normal arrangement of hepatic cells (Mag x 400). 


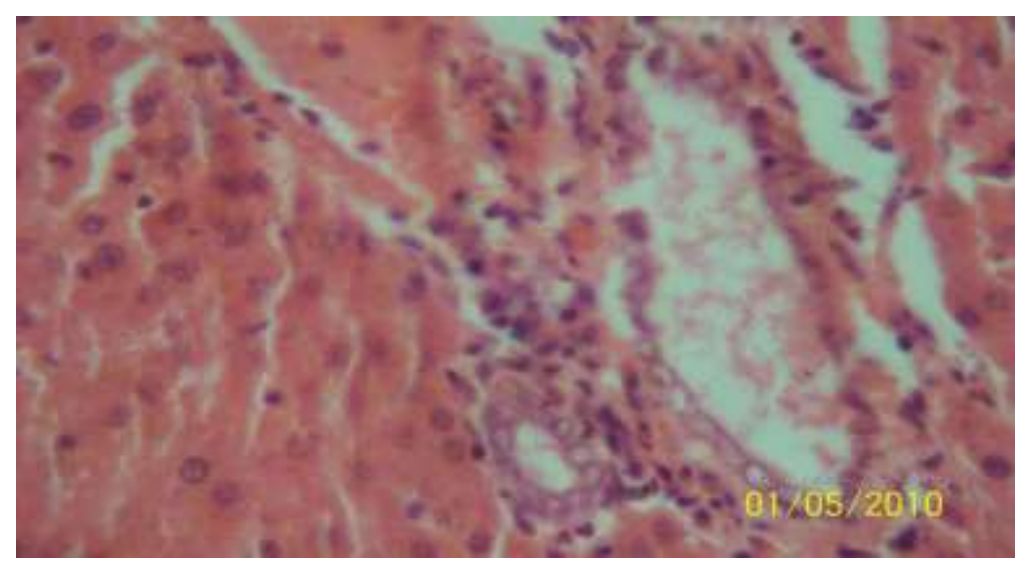

Figure 2(b): Liver section from group $2\left(\mathrm{CCl}_{4}\right)$ showing periportal hepatic necrosis/cellular infiltration, bile duct hyperplasia and central lobular fatty regeneration (Mag x 400).

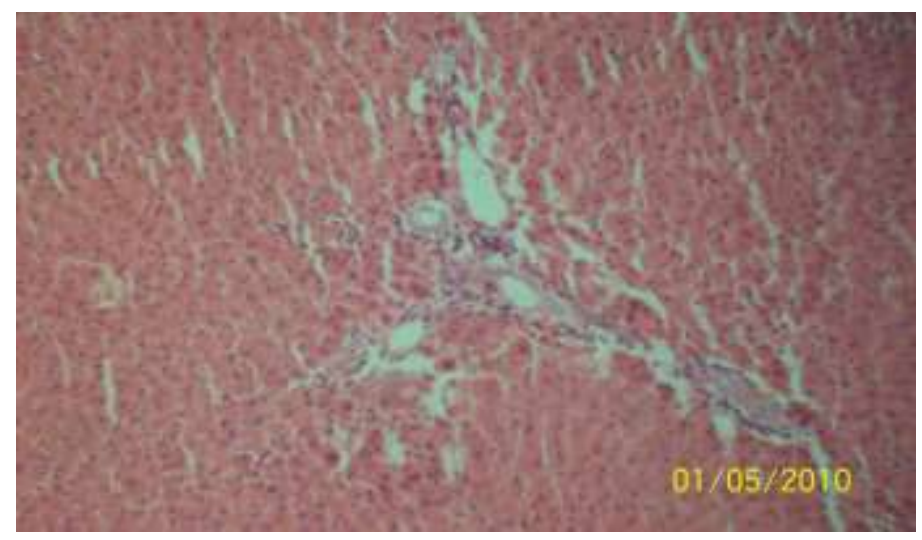

Fig 2(c): Liver section from group $3\left(\mathrm{CCl}_{4}+\right.$ ethylacetate fraction of leaves $)$ showing periportal hepatic necrosis/cellular infiltration (mild), bile duct hyperplasia (Mag x 400).

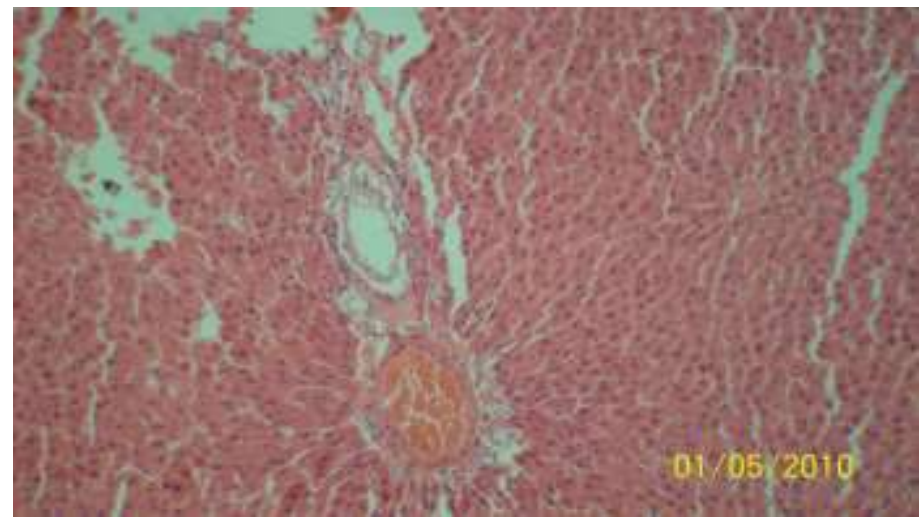

Figure $2(\mathrm{~d})$ : Liver section from group $4\left(\mathrm{CCl}_{4}+\right.$ ethylacetate fraction of bark) showing portal congestion (mild), moderate bile duct hyperplasia (Mag x 400). 


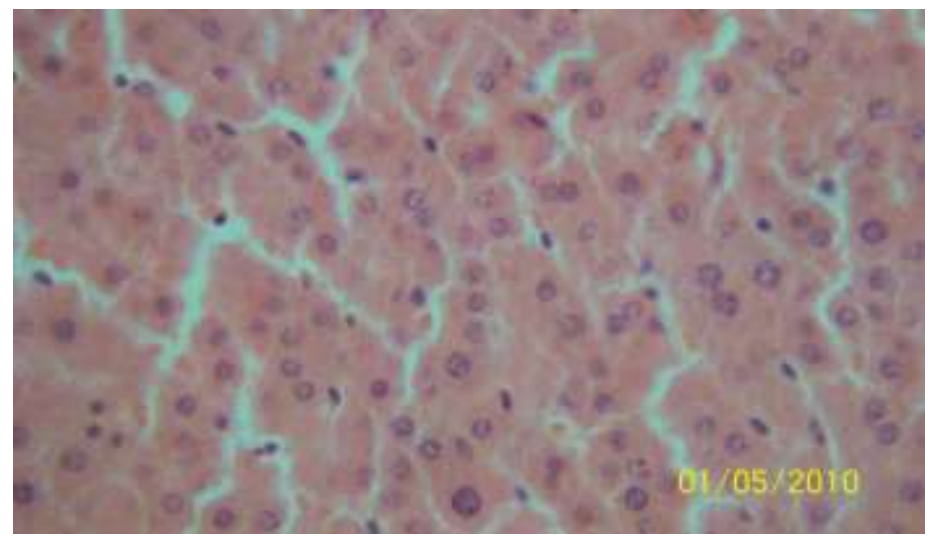

Figure 2(e): Liver section from group 5 (ethylacetate fraction of leaves) showing no visible lesions (Mag x 400).

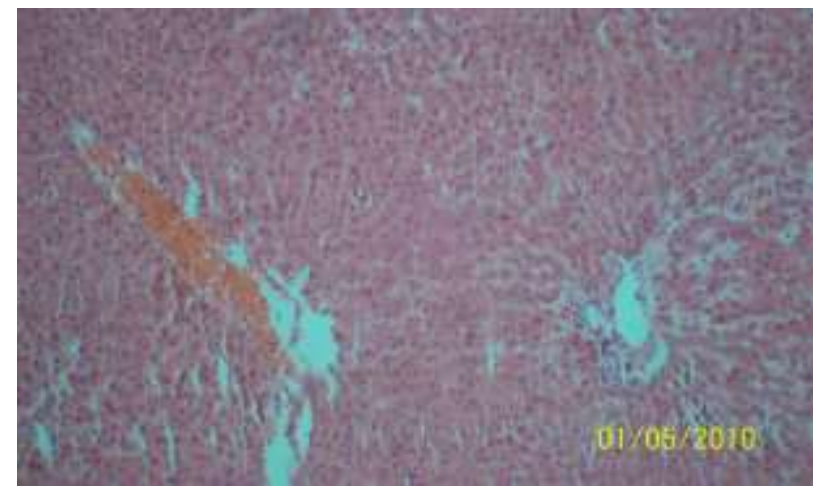

Figure 2(f): Liver section from group 6 (ethylacetate fraction of stem bark) showing portal congestion (mild) and moderate normal arrangement of hepatocytes around the central vein and absence of necrosis (Mag x 400). 


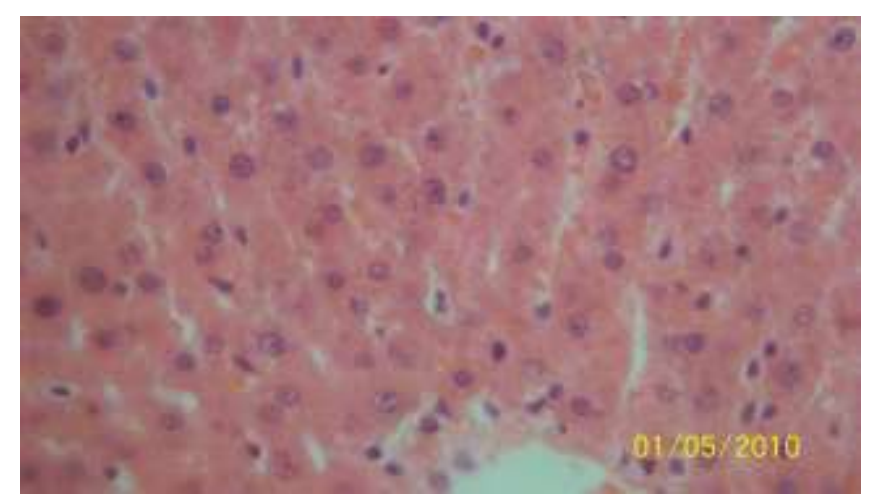

Figure 2(g): Liver section from group $7\left(\mathrm{CCl}_{4}+\right.$ kola viron) showing no visible lesions (Mag $\mathrm{x} 400)$.

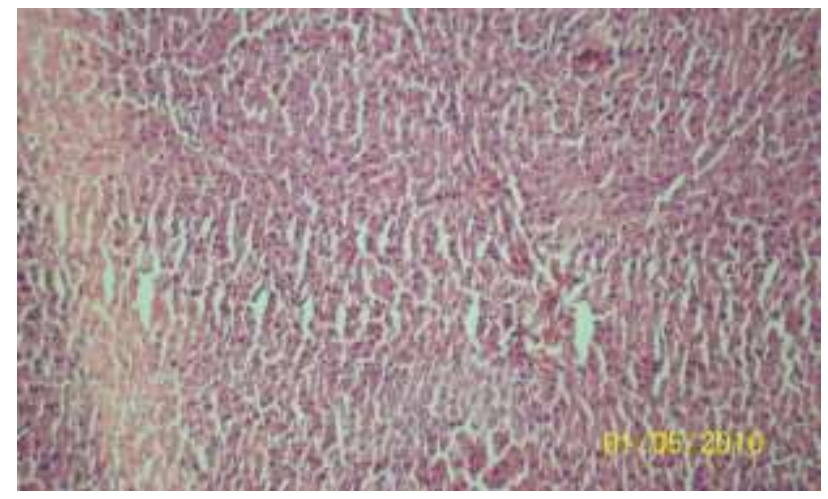

Figure 2(h): Liver section from group 8 (kola viron only) showing moderate normal arrangement of hepatocytes around the central vein (Mag x 400). 